\title{
Acholeplasma Species Differentiation with the Growth Precipitation Test
}

\author{
J. HEITMANN AND H. KIRCHHOFF \\ Institut für Mikrobiologie und Tierseuchen der Tierärztlichen Hochschule, D 3000 Hannover, Federal \\ Republic of Germany
}

\begin{abstract}
The suitability of the growth precipitation test for differentiation of 43 Acholeplasma strains belonging to seven different species was examined. Cross-growth precipitation tests indicated a high degree of specificity of this method, which makes possible the simple and reliable identification of Acholeplasma species.
\end{abstract}

The growth precipitation test (GPT) described by Krogsgaard-Jensen in 1972 (5) is a simple and specific serodiagnostic method that has proven suitable for the identification of several Mycoplasma species $(2,5)$. The disk growth inhibition test described by Clyde (1) was combined with the GPT by Jordan (3), who utilized this combined test for the classification of avian mycoplasmas.

The purpose of this investigation was to determine the suitability of the GPT for differentiation of Acholeplasma species.

\section{MATERLALS AND METHODS}

Acholeplasma strains. The Acholeplasma strains employed in this investigation and their sources are listed in Table 1.

Culture medium. The liquid medium consisted of: heart infusion broth (Difco), $720 \mathrm{ml}$; unheated horse serum, $200 \mathrm{ml}$; fresh yeast extract, 25\% (wt/vol), 10 $\mathrm{ml}$; deoxyribonucleic acid (Sigma Chemical Co.), 0.02 $\mathrm{g}$; thallium acetate, $1.25 \%(\mathrm{wt} / \mathrm{vol}), 10 \mathrm{ml}$; and penicillin, $2 \times 10^{\text {i }}$ IU.

Solid medium was prepared by adding $1.5 \%$ (wt/vol) PPLO agar (Difco) to the liquid medium.

Rabbit antisera. Preparation of antisera and their properties in other serological tests have been described elsewhere (4).

GPT. The GPT was performed by the method of Krogsgaard-Jensen (5) with some modifications. The central well had a diameter of $7 \mathrm{~mm}$; it was filled with $0.05 \mathrm{ml}$ of antigen by means of a micropipette.

Antigens were prepared as follows. Agar blocks (ca. 1 by $1 \mathrm{~cm}$ ) showing dense growth of organisms were placed into $2-\mathrm{ml}$ volumes of liquid medium. The tubes were shaken intensively and left at room temperature for approximately $1 \mathrm{~h}$; then the cultures were used as antigens.

Filter paper disks, $6 \mathrm{~mm}$ in diameter, were impregnated with $0.025 \mathrm{ml}$ of antiserum and placed on the agar surface at a distance of $1 \mathrm{~cm}$ from the rim of the central well. In some cases we got better results by placing the same amount of antiserum into wells 4 $\mathrm{mm}$ in diameter. The distance between the central well and wells containing serum was $1 \mathrm{~cm}$, too. The agar plates were incubated at $37^{\circ} \mathrm{C}$ in a humid atmos- phere containing $5 \% \mathrm{CO}_{2}$. Reactions were read against a dark background with obliquely transmitted light. The results of the test were recorded after 5 days of incubation.

\section{RESULTS}

Precipitation lines became visible after 2 to 3 days of incubation and increased in intensity in the following days (Fig. 1 and 2).

The results of the cross-GPT with 43 Acholeplasma strains and antisera against seven different Acholeplasma species are demonstrated in Table 2. All strains could be identified by this method, and none of them showed any cross-reaction with antisera against other species.

\section{DISCUSSION}

The simple and specific species differentiation of acholeplasmas by means of their biochemical properties is not yet possible because of the lack of suitable tests. Strains within one species frequently differ in biochemical behavior in established tests (7). This is why species identification most often is made by means of serological methods, the most usual being metabolic inhibition (6), direct and indirect immunofluorescence, and growth inhibition (1). The metabolic inhibition test is characterized by a good degree of specificity (4), but it is laborious to perform. The direct immunofluorescence test requires suitable conjugated antisera and appropriate technical equipment, the latter being necessary for the indirect immunofluorescence test, too. This test, performed with Acholeplasma colonies on agar blocks, sometimes gives cross-reactions between the different Acholeplasma species $(4,8)$. Furthermore, slight autofluorescence of colonies often occurs (4), making interpretation of results difficult. The growth inhibition test is of doubtful value for the differentiation of Acholeplasmataceae, because cross-reactions appear quite often $(4,7)$. Furthermore, difficulties arise in 
TABLE 1. Acholeplasma strains studied

\begin{tabular}{|c|c|c|c|}
\hline $\begin{array}{c}\text { Acholeplasma spe- } \\
\text { cies }\end{array}$ & $\begin{array}{c}\text { Strain designa- } \\
\text { tion }\end{array}$ & Origin & Source $^{a}$ \\
\hline A. laidlawii & $\begin{array}{l}\text { PG } 8 \\
\text { PG } 9 \\
739 \\
779 \\
780 \\
814 \\
944 \\
1011 \\
1092 \\
\text { KD } 135 \\
\text { A } 42 \text { Hzbtl. } \\
\text { D } 853 \\
\text { D } 869 \\
\text { A } 1 \\
\text { A } 2 \\
\text { A } 3 \\
\text { A } 4 \\
\text { A } 5 \\
\text { A } 6 \\
\text { A } 7 \\
\text { D } 1251 \\
\text { D } 1252 \\
\text { D } 1253 \\
\text { D } 1254\end{array}$ & $\begin{array}{l}\text { Sewage } \\
\text { Sewage } \\
\text { Unknown } \\
\text { Unknown } \\
\text { Unknown } \\
\text { Unknown } \\
\text { Unknown } \\
\text { Unknown } \\
\text { Unknown } \\
\text { Unknown } \\
\text { Dog } \\
\text { Horse } \\
\text { Horse } \\
\text { Swine } \\
\text { Swine } \\
\text { Swine } \\
\text { Swine } \\
\text { Swine } \\
\text { Swine } \\
\text { Swine } \\
\text { Human } \\
\text { Human } \\
\text { Human } \\
\text { Human }\end{array}$ & $\begin{array}{l}\text { I } \\
\text { I } \\
\text { I } \\
\text { I } \\
\text { I } \\
\text { I } \\
\text { I } \\
\text { I } \\
\text { I } \\
\text { VII } \\
\text { VII } \\
\text { VII } \\
\text { V } \\
\text { V } \\
\text { V } \\
\text { V } \\
\text { V } \\
\text { V } \\
\text { V } \\
\text { VI } \\
\text { VI } \\
\text { VI } \\
\text { VI }\end{array}$ \\
\hline A. granularum & BTS-39 & Swine & II \\
\hline A. oculi & $\begin{array}{l}19 \mathrm{~L} \\
215 \\
\text { FJ } 4 \\
\text { AF } 9 \text { Liv. } \\
\text { AF } 12 \text { Plac. } \\
\text { NS } 269 \\
\text { NS } 271 \\
\text { CSF-1 } \\
\text { CSF-2 }\end{array}$ & $\begin{array}{l}\text { Goat } \\
\text { Horse } \\
\text { Horse } \\
\text { Horse } \\
\text { Horse } \\
\text { Horse } \\
\text { Horse } \\
\text { Horse } \\
\text { Horse }\end{array}$ & $\begin{array}{l}\text { II } \\
\text { IV } \\
\text { IV } \\
\text { IV } \\
\text { IV } \\
\text { IV } \\
\text { IV } \\
\text { IV } \\
\text { IV }\end{array}$ \\
\hline A. axanthum & S-743 & $\begin{array}{l}\text { Tissue } \\
\text { culture }\end{array}$ & III \\
\hline A. modicum & PG 49 & Cattle & II \\
\hline $\begin{array}{l}\text { A. equifetale (pro- } \\
\text { posed species) }\end{array}$ & $\begin{array}{l}\text { C } 112 \\
\text { C } 589 \\
\text { C } 117 \\
\text { C } 581\end{array}$ & $\begin{array}{l}\text { Horse } \\
\text { Horse } \\
\text { Horse } \\
\text { Horse }\end{array}$ & $\begin{array}{l}\text { VII } \\
\text { VII } \\
\text { VII } \\
\text { VII }\end{array}$ \\
\hline $\begin{array}{l}\text { A. hippikon (pro- } \\
\text { posed species) }\end{array}$ & $\begin{array}{l}\text { C } 1 \\
\text { M } 83 \\
\text { M } 94\end{array}$ & $\begin{array}{l}\text { Horse } \\
\text { Horse } \\
\text { Horse }\end{array}$ & $\begin{array}{l}\text { VII } \\
\text { VII } \\
\text { VII }\end{array}$ \\
\hline
\end{tabular}

${ }^{a}$ I, National Institutes of Health, Bethesda, Md.; II, FAO/ WHO International Reference Center for Animal Mycoplasmas, Aarhus, Denmark; III, National Collection of Type Cultures, London, England; IV, University of Queensland, Brisbane, Australia; V, State Veterinary Serum Laboratory, Copenhagen, Denmark; VI, Hygienisch-Bakteriologisches Landesuntersuchungsamt Westfalen, Muenster, Federal Republic of Germany; VII, this laboratory.

preparation of rabbit hyperimmune antisera containing growth-inhibiting antibodies, for some rabbits seem not to develop such antibodies.

The GPT used in this study for identification of Acholeplasma species can be performed easily and quickly; no special preparation of antigen

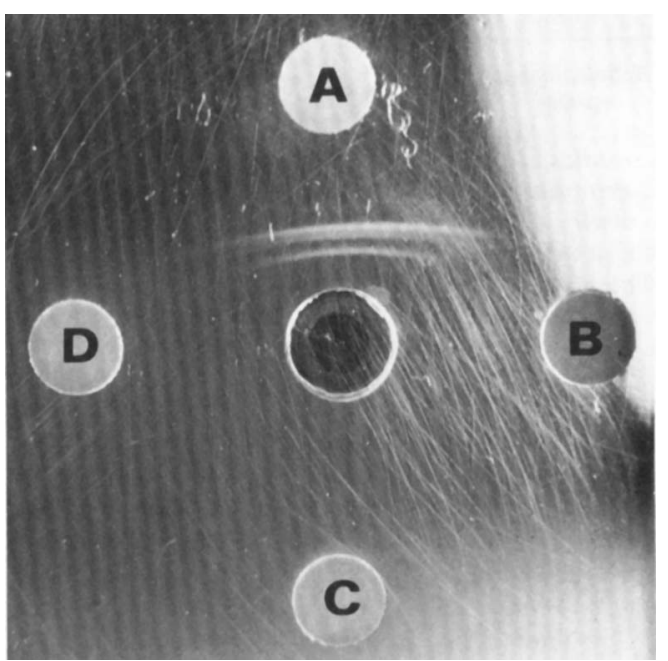

FIG. 1. Antigen in central well: $A$. laidlawii $P G$ 8. Antisera: (A) PG 8; (B) BTS-39; (C) $19 \mathrm{~L}$; (D) C 589.

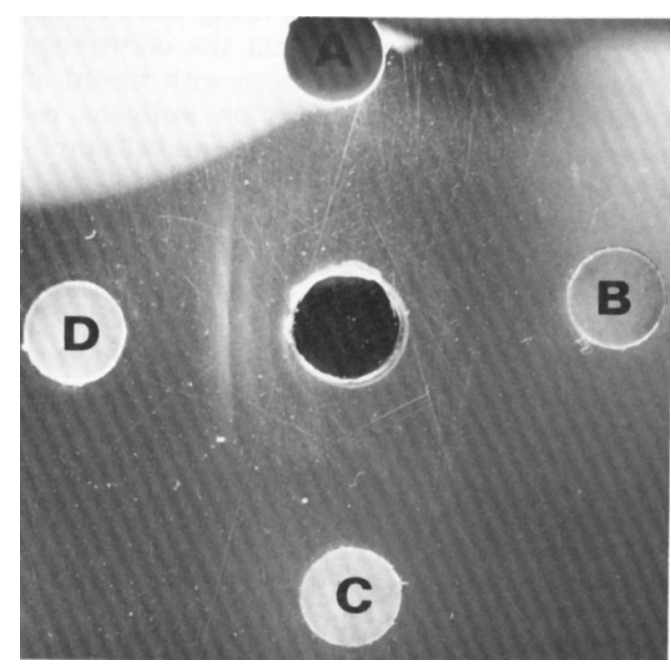

Fig. 2. Antigen in central well: A. equifetale $C$ 589. Antisera: See legend to Fig. 1.

or standardization of colony-forming units is necessary. Krogsgaard-Jensen (5) found that the composition of the medium had no influence on the reaction. Furthermore, the test could be successfully performed with hyperimmune sera having no demonstrable growth-inhibiting antibodies.

Tully (7) did not find the GPT sufficiently sensitive for identifying all $A$. laidlawii strains he had examined. In contrast to these observations, in our study precipitation lines with all $24 \mathrm{~A}$. laidlawii strains tested and antiserum against the PG 8 strain were obtained. A high 
TABLE 2. Results of GPT of $\mathbf{4 3}$ acholeplasma strains with seven different species-specific antisera

\begin{tabular}{|c|c|c|c|c|c|c|c|c|}
\hline \multirow{2}{*}{$\begin{array}{c}\text { Acholeplasma } \\
\text { species }\end{array}$} & \multirow{2}{*}{ Strain designation } & \multicolumn{7}{|c|}{ Antiserum against: } \\
\hline & & PG 8 & BTS-39 & $19 \mathrm{~L}$ & S-743 & PG 49 & C 112 & C 1 \\
\hline A. laidlawii . . & All strains tested & + & - & - & - & - & - & - \\
\hline A. granularum & BTS-39 & - & + & - & - & - & - & - \\
\hline A. oculi . . . & All strains tested & - & - & + & - & - & - & - \\
\hline A. axanthum & S-743 & - & - & - & + & - & - & - \\
\hline A. modicum & PG 49 & - & - & - & - & + & - & - \\
\hline A. equifetale & All strains tested & - & - & - & - & - & + & - \\
\hline A. hippikon & All strains tested & - & - & - & - & - & - & + \\
\hline
\end{tabular}

degree of specificity of the GPT was demonstrated. In cross-GPT's with 43 Acholeplasma strains of different species and with antisera against all established Acholeplasma species, no cross-reactions occurred; positive reactions were easy to read.

The use of broth cultures, which have been frozen or lyophilized, as antigens directly after thawing or rehydration, respectively, should be avoided. We observed that some of those cultures reacted with more than one serum, but we never got cross-reactions using the method described above. It seems that the occurrence of unspecific precipitation lines with frozen or lyophilized cultures depends on antigens released from disrupted Acholeplasma cells probably being present in the broth.

It can be concluded that the GPT is suitable for typing Acholeplasma species. It is technically simple to perform and has a high degree of specificity. Additional tests with more field strains of acholeplasmas and reference sera should be done to further evaluate this method for routine diagnostic purposes.

\section{ACKNOWLEDGMENTS}

We thank M. F. Barile, E. A. Freundt, N. F. Friis, and A. R. S. Moorthy for providing Acholeplasma cultures. Furthermore, we are greatly indebted to $M$. F. Barile and $R$. F. Ross for much valuable advice.

\section{REPRINT REQUESTS}

Address reprint requests to: Dr. J. Heitmann and Dr. $H$. Kirchhoff, Bischofsholer Damm 15, D 3000 Hannover 1, Federal Republic of Germany.

\section{LTERATURE CITED}

1. Clyde, W. A., Jr. 1964. Mycoplasma species identification based upon growth inhibition by specific antisera J. Immunol. 92:958-965.

2. Gois, M., and F. Kuska. 1975. Diagnosis and differentiation of porcine mycoplasmas by the growth-precipitation test. Zentralbl. Veterinaermed. Reihe B 22:850-855.

3. Jordan, F. T. W. 1973. A combined growth-inhibition and growth-precipitation test for the typing of avian Mycoplasma. Res. Vet. Sci. 14:387-389.

4. Kirchhoff, H. 1978. Acholeplasma equifetale and Acholeplasma hippikon, two new species from aborted horse fetuses. Int. J. Syst. Bacteriol. 28:76-81.

5. Krogegaard-Jensen, A. 1972. Mycoplasma: growth precipitation as a serodiagnostic method. Appl. Microbiol. 23:553-558.

6. Taylor-Robinson, D., R. H. Purcell, D. C. Wong, and R. M. Chanock. 1966. A colour test for the measurement of antibody to certain Mycoplasma species based upon the inhibition of acid production. J. Hyg. 64:91-104.

7. Tully, J. G. 1973. Biological and serological characteristics of the Acholeplasma. Ann. N.Y. Acad. Sci. 225: 74-93.

8. Tully, J. G., and S. Razin. 1968. Physiological and serological comparisons among swine strains of $\mathrm{Myco}$. plasma granularum and Mycoplasma laidlawii. J. Bacteriol. 95: 1504-1512. 